\title{
Polysaccharides from Lichens: Structural Characteristics and Biological Activity
}

\author{
Elin S. Olafsdottir*, Kristín Ingólfsdottir \\ Faculty of Pharmacy, University of Iceland, Reykjavik, Iceland \\ Received: June 19, 2000; Accepted: October 8, 2000
}

\begin{abstract}
Lichens have been used for medicinal purposes throughout the ages, and beneficial claims have to some extent been correlated with their polysaccharide content. Of $13,500 \mathrm{li}$ chen species growing worldwide, less than 100 species have been investigated for polysaccharide content. Lichen polysaccharides are mainly of three different structural types: $\beta$-glucans, $\alpha$-glucans, and galactomannans. In addition, a few complex heteroglycans have recently been described, such as thamnolan, a water-soluble, immunologically active heteroglycan with a novel rhamnopyranosylgalactofuranan type of structure. A number of investigations have been carried out on biological effects of lichen polysaccharides, most notably antitumour, immunomodulating, antiviral, and memory-enhancing effects. The current review summarizes present knowledge on the structural characteristics and biological activity of lichen polysaccahrides.
\end{abstract}

Key words: Lichens, polysaccharides, structural characteristics, antitumour activity, immunological activity, biological activity.

\section{Introduction}

Lichens are slow-growing symbiotic organisms consisting of a fungus and an algae. The symbiosis is beneficial for both partners and allows them to live under harsh conditions such as extremes in moisture and temperature. Lichens count about 13,500 species growing throughout the world. About one third of them have been investigated for low molecular weight compounds and found to produce over 200 different secondary metabolites such as aromatic polyketides, many of which have been shown to be biologically active (1).

Less than 100 species of lichens have been investigated for polysaccharide constituents and found to produce three main structural types: $\alpha$-glucans, $\beta$-glucans, and galactomannans $(2-5)$. Recently complex heteroglycans isolated from lichens have been described (6), (7). Lichen polysaccharides of the $\beta$ glucan and galactomannan type have been suggested to be of chemotaxonomic significance (2), (8), (9).

Planta Med 67 (2001) 199-208

(c) Georg Thieme Verlag Stuttgart · New York ISSN: 0032-0943
Lichen polysaccharides which can be isolated in considerable yield such as the $\alpha$-glucans, $\beta$-glucans, and galactomannans are generally expected to be of fungal origin (2), (4). This is supported by results of an investigation on the polysaccharide content of several lichen mycobionts and phycobionts grown separately, where it was found that the mycobiont produced polysaccharides similar to those of the parent lichen while the phycobiont produced different polysaccharides (10). However, a polysaccharide similar in monosaccharide composition to the complex lichen heteropolysaccharide, thamnolan, discussed below, has been described as a component of a phycobiont cell wall (11). The localisation of the lichen polysaccharides has not been established, they could either be a part of the fungal cell wall or reserve glucans, and they could be intracellular or a part of the intercellular material which surrounds both algal and fungal cells (12).

Several lichen species, such as Cetraria islandica and Lobaria pulmonaria, have been used in traditional medicine since ancient times, to treat a variety of illnesses (13). The possible role of polysaccharides in their beneficial action has been suggested (14). All lichen species investigated so far produce polysaccharides in considerable amounts, up to $57 \%$ (15), and many of them have been shown to exhibit antitumour, immunostimulating, antiviral as well as other types of biological activity.

\section{Structural Characteristics}

Polysaccharides isolated from lichens are primarily linear or scarcely substituted $\alpha$ - or $\beta$-glucans. Secondly, several galactomannan-type structures have been reported, and thirdly a few complex heteroglycans, including a totally new rhamnopyranosylgalactofuranan structure, were recently described (6). The lichen species which have been investigated so far for polysaccharide content are grouped according to families and listed in Table 1, with an overall description of their respective structures. The different structures are described in more detail in Tables $\mathbf{2}$ through $\mathbf{5}$, together with chemical and physical properties, and discussed in the sections below. Reported NMR shifts are included, especially for the anomeric carbons and protons, as they can be very helpful in analysing structural details of the lichen polysaccharides such as linkage types and linkage type ratios. 
Table 1 Lichen species which have been investigated for polysaccharide content - structural types

\begin{tabular}{|c|c|c|c|c|c|}
\hline Family/Species & $\beta$-Glucana & $\begin{array}{l}\text { Structural types } \\
\alpha \text {-Glucan }{ }^{\mathrm{a}}\end{array}$ & $\begin{array}{l}\text { Galactomannan } \\
\text { ratio: Man/Gal/Glc }\end{array}$ & Others & Ref. \\
\hline \multicolumn{6}{|l|}{ Cladoniaceae } \\
\hline Cladonia alpestris & & nigeran type $(1: 1)$ & $57: 31: 12$ & & 25 \\
\hline C. amaurocraea & pustulan & & $66: 24: 09$ & & 25 \\
\hline C. bellidiflora & & nigeran type $(1: 1)$ & & & 26 \\
\hline C. clathrata & & nigeran type $(1: 1)$ & & & 27 \\
\hline C. confusa & & nigeran type $(1: 1)$ & $42: 51: 07$ & & 25 \\
\hline C. connexa & & nigeran type $(1: 1)$ & & & 27 \\
\hline C. crispata & & nigeran type $(1: 1)$ & & & 28 \\
\hline C. crispatula & & nigeran type $(1: 1)$ & & & 27 \\
\hline C. furcata & & nigeran type $(1: 1)$ & & & 27 \\
\hline C. ibitipocae & & nigeran type $(1: 1)$ & $35: 60: 2$ & & 27,29 \\
\hline C. imperialis & & nigeran type $(1: 1)$ & & & 27 \\
\hline C. mitis & & nigeran type $(1: 1)$ & & & 28 \\
\hline C. pacifica & & nigeran type $(1: 1)$ & & & 26 \\
\hline C. penicillata & & nigeran type $(1: 1)$ & & & 27 \\
\hline C. rangiferina & & nigeran type $(1: 1)$ & & & 28 \\
\hline C. signata & & nigeran type (1:1) & & & 27 \\
\hline C. squamosa & & nigeran type $(1: 1)$ & & & 28 \\
\hline C. substellata & & & $27: 59: 12$ & & 29 \\
\hline \multicolumn{6}{|l|}{ Parmeliaceae } \\
\hline Cetraria cucullata & lichenan $(1: 2)$ & isolichenan $(2: 1)$ & $55: 35: 10$ & & 30 \\
\hline C. islandica & lichenan $(3: 7)$ & isolichenan $(3: 2)$ and $\mathrm{Ci}-3(2: 1)$ & $47: 46: 07$ & Ki-M-7 & $5,20,24,31$ \\
\hline C. nivaris & lichenan & isolichenan & & & 32 \\
\hline C. richardsonii & lichenan $(3: 7)$ & isolichenan $(3: 2)$ & & & 33 \\
\hline Evernia prunastri & lichenan $(3: 1)$ & $\begin{array}{l}\text { isolichenan }(4: 1) \text { and }(3: 2) \\
\text { nigeran type }(1: 1) \text { incl. } 1,2 \text {-linkages } \\
\text { isolichenan }(6: 1) \text { incl. 1,6-linkages }\end{array}$ & $49: 42: 09$ & & $2,17,34,35$ \\
\hline Letharia vulpina & lichenan $(1: 3)$ & nigeran type $(1.2: 1)$ & galman & & 36,37 \\
\hline Newropogon aurantiaco-ater & lichenan $(1: 2)$ & isolichenan $(3: 2)$ & $53: 44: 03$ & & 15 \\
\hline Parmelia caperata & & isolichenan $(3: 2)$, nigeran type $(1: 1)$ & & & $28,38,39$ \\
\hline P. cetrarioides & & isolichenan, nigeran type $(1: 1)$ & & & 26 \\
\hline P. conspersa & lichenan & isolichenan & & & 26 \\
\hline P. hypotrypella & lichenan & isolichenan & & & 26 \\
\hline P. laevior & & isolichenan, nigeran type $(1: 1)$ & & & 26 \\
\hline P. nikkoensis & lichenan & isolichenan & & & 26 \\
\hline P. saxatilis & & isolichenan $(2: 1)$, nigeran type $(1.3: 1)$ & & & 40 \\
\hline P. tinctorum & lichenan & isolichenan & & & 26 \\
\hline Parmotrema cetrarum & lichenan $(1: 1.9)$ & & $46: 45: 09$ & & 2,34 \\
\hline P. araucaria & & & $50: 44: 6,49: 44: 7$ & & 34 \\
\hline P. sulcata & & & $42: 44: 12$ & & 37 \\
\hline Usnea barbata & lichenan & isolichenan & & & 32 \\
\hline U. baylei & lichenan & isolichenan & & & 26,41 \\
\hline U. faciata & & isolichenan & & & 42 \\
\hline U. longissima & lichenan & isolichenan & & & 43 \\
\hline U. meridionalis & & & $35: 42: 23 ; 52: 35: 13$ & & 34 \\
\hline U. rubescens & lichenan $(3: 7)$ & & & & 28 \\
\hline Usnea sp. & lichenan $(1: 3)$ & & $33: 47: 21,35: 61: 4$ & & 36,37 \\
\hline \multicolumn{6}{|l|}{ Peltigeraceae } \\
\hline Peltigera aphthosa & & & $38: 44: 11$ & & 37 \\
\hline \multicolumn{6}{|l|}{ Umbellicariaceae } \\
\hline Actinogyra muehlenbergii & pustulan & & $58: 37: 05$ & & 36,37 \\
\hline Gyrophora esculenta & pustulan & & & & 44 \\
\hline Lasallia papulosa & pustulan & & & & 44 \\
\hline L. pensylvanica & pustulan & & & & 28 \\
\hline Umbilicaria angulata & pustulan & & & & 45 \\
\hline U. caroliniana & pustulan & & & & 45 \\
\hline U. hirsuta & pustulan & & & & 44,46 \\
\hline U. polyphylla & pustulan & & & & 45 \\
\hline U. pustulata & pustulan & & $40: 20: 30$ & & 46,47 \\
\hline U. spodochroa & & & $32: 19: 32$ & & 47 \\
\hline
\end{tabular}


Table 1 cont.

\begin{tabular}{|c|c|c|c|c|c|}
\hline Family/Species & $\beta$-Glucan ${ }^{\mathrm{a}}$ & $\begin{array}{l}\text { Structural types } \\
\alpha \text {-Glucan }\end{array}$ & $\begin{array}{l}\text { Galactomannan } \\
\text { ratio: Man/Gal/Glc }\end{array}$ & Others & Ref. \\
\hline \multicolumn{6}{|l|}{ Ramalinaceae } \\
\hline Ramalina celastri & laminaran type & isolichenan $(3: 1)$, nigeran type $(1: 1)$ & & & 48 \\
\hline R. ecklonii & & isolichenan $(3: 1)$ & $36: 50: 14$ & & 34,49 \\
\hline R. scopulorum & & & & & 41 \\
\hline R. usnea & laminaran type & isolichenan (3.8:1) incl. 1,2-linkages & $38: 44: 18$ & & 31 \\
\hline \multicolumn{6}{|l|}{ Lichen imperfecti } \\
\hline Thamnolia subuliformis & & & & thamnolan & 6 \\
\hline \multicolumn{6}{|l|}{ Caliaciaceae } \\
\hline Acroscyphus sphaerophoides & & $\begin{array}{l}(2: 3) \text { incl. } 6 \% \text { 1,6-linkages } \\
\text { acroscyphan }\end{array}$ & & & 33 \\
\hline \multicolumn{6}{|l|}{ Alectoriaceae } \\
\hline Alectoria sulcata & lichenan & isolichenan & & & 17 \\
\hline A. sarmentosa & lichenan & isolichenan & & & 17 \\
\hline \multicolumn{6}{|l|}{ Sphaerophoraceae } \\
\hline Sphaerophorus globosus & & $\begin{array}{l}(2: 3) \text { incl. } 6 \% 1,6 \text {-linkages } \\
\text { acroscyphan type }\end{array}$ & & & 33 \\
\hline \multicolumn{6}{|l|}{ Stereocaulaceae } \\
\hline Stereocaulon excutum & & isolichenan $(3: 1)$ & & & 50 \\
\hline St. japonicum & & isolichenin $(2: 1)$ & & & 33,51 \\
\hline St. paschale & & acroscyphan type $(2: 5)$ & $52: 36: 12$ & & 37,52 \\
\hline St. ramulosum & laminaran type & nigeran type $(1: 1)$ & $57: 43: 00$ & & 53,54 \\
\hline St. sorediiferum & & isolichenan $(3: 1)$ & & & \\
\hline \multicolumn{6}{|l|}{ Rocellaceae } \\
\hline Roccella montagnei & lichenan & isolichenan & & & 43 \\
\hline \multicolumn{6}{|l|}{ Lobariaceae } \\
\hline Pilophoron ocicularis & & isolichenan $(2: 1)$ & & & 33 \\
\hline Pseudocyphellaria aurata & & & $61: 30: 19$ & & 34 \\
\hline Sticta sp. & no glucan & no glucan & $63: 21: 16$ & & 55 \\
\hline \multicolumn{6}{|l|}{ Dictyonemataceae } \\
\hline $\begin{array}{l}\text { Cora pavonia } \\
\text { (now: Dictyonema glabratum) }\end{array}$ & $(1 \rightarrow 3),(1 \rightarrow 6)$-glucan & & & CP-heteroglycan & 7 \\
\hline \multicolumn{6}{|l|}{ Pysciaceae } \\
\hline Tornabenia intricata & & & $93: 00: 09$ & & 34 \\
\hline \multicolumn{6}{|l|}{ Collemataceae } \\
\hline Collema leptosporum & $(1 \rightarrow 3),(1 \rightarrow 6)$-glucan & & $35: 00: 65,82: 18: 00$ & CL-heteroglycan & 23 \\
\hline
\end{tabular}

a Ratio of $(1 \rightarrow 3)$ and $(1-4)$ linkages in parenthesis.

\section{$\beta$-Glucans}

The first polysaccharide fraction isolated from a lichen species was a mixture of lichenan and isolichenan isolated from $\mathrm{Ce}$ traria islandica in 1813 by Berzelius (16). Lichenan is a coldwater insoluble, gel-forming, linear $(1 \rightarrow 3)-(1 \rightarrow 4)-\beta$-D-glucan with a linkage ratio of $3: 7$ (Table 2 ). A number of $\beta$-glucans with lichenan-type of structures differing in the ratio of $(1 \rightarrow 3)$ and $(1 \rightarrow 4)$ linkages, are listed in Table 2 . The cold water-soluble lichenan-type of $\beta$-glucan from Evernia prunastri has a linkage ratio of $3: 1$ with the $(1 \rightarrow 3)$-linkage dominating, which is reversed compared to lichenan (17). Pustulan, which is found in almost all species investigated belonging to the family of Umbilicariaceae (Table $\mathbf{1}$ ) is a linear $(1 \rightarrow 6)-\beta$-D-glu- can which may be 0-3-acetylated (Table 2 ). The acetyl groups give characteristic bands in the IR spectrum and a high field signal at $\delta=22.1 \mathrm{ppm}$ in the ${ }^{13} \mathrm{C}-\mathrm{NMR}$ spectrum and at $\delta=$ $2.1 \mathrm{ppm}$ in the ${ }^{1} \mathrm{H}-\mathrm{NMR}$ spectrum.

Other $\beta$-glucans found in lichens are linear $(1 \rightarrow 3)-\beta$-D-glucans (laminaran-type) currently found in three lichen species (Tables 1 and 2 ), and an 0-6-substituted $(1 \rightarrow 3)-(1 \rightarrow 6)-\beta$-D-glucan from Cora pavonia and Collema leptosporum (Table 2 ). The mean molecular weights of the $\beta$-glucans are reported to be between 20 and $62 \mathrm{kD}$. Optical rotation measurements of $\beta$ glucans give positive, low values, except for pustulan which has a negative optical rotation of $-37^{\circ}$ (Table 2 ). The three-dimensional structure of lichenan has been analysed by X-ray 
Table $2 \beta$-Glucans from lichens - structural characteristics and analytical data (see Table 1 for further references)

\begin{tabular}{|c|c|c|c|c|c|c|c|c|c|c|c|}
\hline Structural type & $\begin{array}{l}\text { Linkages in } \\
\text { main chain }\end{array}$ & $\begin{array}{l}\text { Linkage } \\
\text { ratio }\end{array}$ & $\begin{array}{l}\text { Side chains } \\
\text { or substitution }\end{array}$ & $\begin{array}{l}M_{r} \\
\text { in } k D\end{array}$ & $\begin{array}{l}{[\alpha]_{\mathrm{D}}} \\
\operatorname{deg}\end{array}$ & $\begin{array}{l}\text { Sol. in } \\
\text { cold } \mathrm{H}_{2} \mathrm{O}\end{array}$ & $\begin{array}{l}\mathrm{IR \operatorname {max }} \\
\mathrm{Cm}^{-1}\end{array}$ & $\begin{array}{l}\text { NMR-shifts } \\
{ }^{1} \mathrm{H} \text {-NMR }\end{array}$ & $\begin{array}{l}\text { (anomeric and others) } \\
{ }^{13} \mathrm{C}-\mathrm{NMR}\end{array}$ & $\begin{array}{l}\text { NMR } \\
\text { sol/temp }\end{array}$ & $\begin{array}{l}\text { NMR } \\
\text { ref. }\end{array}$ \\
\hline lichenan & $(1 \rightarrow 3),(1 \rightarrow 4)$ & $(3: 7)$ & linear & $20-35$ & $5+8$ & insol. & 890 & 4.44 & $\begin{array}{l}103.4,102.4 \\
102.5,87.0,80.2 \\
79.9,60.4\end{array}$ & $\begin{array}{l}\text { DMSO- } d_{6} / \\
60{ }^{\circ} \mathrm{C}\end{array}$ & 30,56 \\
\hline lichenan & $(1 \rightarrow 3),(1 \rightarrow 4)$ & $(1: 3)$ & & & -8 & sol. & & & & & \\
\hline lichenan & $(1 \rightarrow 3),(1 \rightarrow 4)$ & $(1: 2)$ & & & +14 & insol. & & & & & \\
\hline $\begin{array}{l}\text { lichenan } \\
\text { (branched) }\end{array}$ & $(1 \rightarrow 3),(1 \rightarrow 4)$ & $(1: 1.9)$ & $\begin{array}{l}\text { branched } \\
\text { (not pure) }\end{array}$ & & +49 & sol. & & & & & \\
\hline lichenan & $(1 \rightarrow 3),(1 \rightarrow 4)$ & $(3: 1)$ & & & +12 & sol. & 890 & & & & \\
\hline $\begin{array}{l}\text { pustulan (acetylated } \\
\text { or not) }\end{array}$ & $(1 \rightarrow 6)$ & & $\begin{array}{l}\text { O-3-acetylated } \\
\text { (ca. 10\%) }\end{array}$ & 20 & -37 & insol. & $\begin{array}{l}1735 \\
1250^{\mathrm{a}}\end{array}$ & $2.1^{\mathrm{a}}$ & $\begin{array}{l}\text { 104.6, 77.4, 76.6, } \\
74.8,71.7,70.6 \\
22.1^{\mathrm{a}}\end{array}$ & $\mathrm{D}_{2} \mathrm{O} / 70^{\circ} \mathrm{C}$ & 4 \\
\hline laminaran type & $(1 \rightarrow 3)$ & & linear & 62 & +10 & insol. & & & $\begin{array}{l}\text { 103.2, 86.4, 76.6, } \\
73.2,68.7,61.1\end{array}$ & $\begin{array}{l}\mathrm{NaOD}-\mathrm{D}_{2} \mathrm{O} / \\
30^{\circ} \mathrm{C}\end{array}$ & 48 \\
\hline $\begin{array}{l}\text { Cora pavonia } \\
\text { glucan }\end{array}$ & $(1 \rightarrow 3),(1 \rightarrow 6)$ & & $\begin{array}{l}\text { branched at } 06 \\
\text { (ca. 20\%) }\end{array}$ & & +13 & sol. & & & $\begin{array}{l}104.5,86.5,68.7 \\
62.6\end{array}$ & $\mathrm{D}_{2} \mathrm{O} / 70^{\circ} \mathrm{C}$ & 7 \\
\hline $\begin{array}{l}\text { Collema leptosporum } \\
\text { glucan }\end{array}$ & $(1 \rightarrow 3), 1 \rightarrow 6)$ & & $\begin{array}{l}\text { branched at } \mathrm{O6} \\
\text { (ca. } 23 \% \text { ) }\end{array}$ & 57 & 0 & sol. & & & $\begin{array}{l}\text { 104.6, 104.4, 86.4, } \\
70.6,62.5\end{array}$ & $\mathrm{D}_{2} \mathrm{O} / 30^{\circ} \mathrm{C}$ & 23 \\
\hline
\end{tabular}

a From the acetyl group.

crystallography and the conformation shown to be a triple helix. Triple helical structures have also been demonstrated for $(1 \rightarrow 3)$ - $\beta$-glucans from several fungi. The introduction of short side chains or $(1 \rightarrow 4)$ or $(1 \rightarrow 6)$ linked residues into the $(1 \rightarrow 3)$ - $\beta$-glucan backbone does not seem to interrupt this triple helix conformation (5), (12).

\section{$\alpha$-Glucans}

Isolichenan was the first $\alpha$-glucan described from lichens. Isolichenan is a cold-water soluble $(1 \rightarrow 3)-(1 \rightarrow 4)-\alpha$-D-glucan originally isolated from Cetraria islandica and reported to have $M_{\mathrm{r}}$ of about $6-8 \mathrm{kD}$ and early reports (18), (19) disagree on the linkage ratio (from $3: 2$ to almost $1: 1$ ). A recent investigation could not confirm the existence of such a small $\alpha$-glucan in C. islandica; instead, a much larger isolichenan with a linkage ratio of 2:1 according to NMR data was found (20). The definitions "isolichenan-type" polysaccharide or sometimes only "isolichenans" have been used for $\alpha$-D-glucans having $(1 \rightarrow 3)-(1 \rightarrow 4)$-linkages in their main chain. By studying Table 3 , it seems that lichens produce isolichenan-type polysaccharides with considerable variation in linkage ratios as well as $M_{\mathrm{r}}$, even within the same species. Occasionally these $\alpha$-glucans can be branched at 02,03 or 06 . Nigeran-type polysaccharides can be defined as a subgroup of the isolichenantype $\alpha$-glucans having a linkage ratio of $1: 1$. Accordingly, acroscyphan-type $\alpha$-glucans can be considered as a subgroup of the isolichenan-type having a high proportion of $(1 \rightarrow 4)$-linkages in the main chain. The nigeran-type $\alpha$-glucans are insoluble in cold water. The optical rotation measurements of the lichen $\alpha$-glucans always give positive high values (Table 3).

\section{Galactomannans}

A polysaccharide fraction from Cetraria islandica containing galactose and mannose was recognized as early as 1906 (21) but more detailed structural investigations on this group of lichen polysaccharides were mainly carried out over the past 15 years. Currently, galactoglucomannans have been isolated from at least 24 different species of lichens (Table 1 ). The main chain always consists of $(1 \rightarrow 6)$-linked $\alpha$-D-mannopyranosyl units. The ratio of Man/Gal/Glc is variable. However, in most cases mannose or almost equivalent proportions of mannose and galactose predominate. The amount of glucose reported in these heteroglycans should be considered with caution as it is possible that the samples might be contaminated with small amounts of accompanying glucans from the lichen. The mannopyranosyl units in the main chain are branched mainly at 02 or 04 by units of $\alpha$ - or $\beta$-Galp, $\alpha$-Man $p$ or Glc $p$ and more rarely by $\beta$-Galf or $\alpha$-Manf (Table 4). Galactomannans with no glucose units attached have been isolated from two lichen species, Collema leptosporum and Stereocaulon ramulosum with monosaccharide Man/Gal ratios of $82: 18$ and 57:43, respectively. More details on their structure can be seen in Table 4. Glucomannans have been reported from Tornabenia intricata and C.leptosporum. The monosaccharide Man/Glc ratios are $93: 7$ and 35:65, respectively (Table 4).

\section{Complex heteroglycans}

A few complex heteroglycans have been isolated from lichens. Polysaccharides containing monosaccharides other than, or in addition to galactose, glucose, mannose are grouped here. The first was isolated in $0.06 \%$ yield from the Basidiomycetous lichen Cora pavonia in 1987 by Iacomini et al. (7) and the structure was shown to be predominated by Man $p$ and Xyl $p$ with a main chain of $(1 \rightarrow 3)$-linked $\alpha$-D-mannopyranosyl units. More details on the structure can be found in Table 5 .

Another totally different heteropolysaccharide, thamnolan, was recently isolated in $0.05 \%$ yield from Thamnolia subuliformis (now: Thamnolia vermicularis var. subuliformis) by Olafsdottir et al. (6). Thamnolan is a rhamnopyranosylgalactofuranan with a structure predominated by $(1 \rightarrow 3)$-linked $\beta$-Dgalactofuranosyl units with complex rhamnopyranosyl side chains and terminal xylose units as described in Table $\mathbf{5}$. The optical rotation of thamnolan which is not previously published, was found to be $[\alpha]_{D}^{23}=-63^{\circ}(c$. 1.0, in water $)$ and is in accordance with the negative literature values reported for 
Table $3 \alpha$-Glucans from lichens - structural characteristics and analytical data (see Table $\mathbf{1}$ for further references)

\begin{tabular}{|c|c|c|c|c|c|c|c|c|c|c|c|}
\hline Structural type & $\begin{array}{l}\text { Linkages in } \\
\text { main chain }\end{array}$ & $\begin{array}{l}\text { Linkage } \\
\text { ratio }\end{array}$ & $\begin{array}{l}\text { Side chains } \\
\text { and comments }\end{array}$ & $\begin{array}{l}M_{\mathrm{r}} \\
\text { in } \mathrm{kD}\end{array}$ & $\begin{array}{l}{[\alpha]_{\mathrm{D}}} \\
\mathrm{deg}\end{array}$ & $\begin{array}{l}\text { Sol. in } \\
\text { cold } \mathrm{H}_{2} \mathrm{O}\end{array}$ & $\begin{array}{l}\mathrm{IRmax} \\
\mathrm{cm}^{-1}\end{array}$ & $\begin{array}{l}\text { NMR-shifts } \\
{ }^{1} \mathrm{H} \text {-NMR }\end{array}$ & $\begin{array}{l}\text { (anomeric and others) } \\
{ }^{13} \text { C-NMR }\end{array}$ & $\begin{array}{l}\text { NMR } \\
\text { sol/temp }\end{array}$ & $\begin{array}{l}\text { NMR } \\
\text { ref. }\end{array}$ \\
\hline isolichenan & $(1 \rightarrow 3),(1 \rightarrow 4)$ & $(3: 2)$ & linear & $6-8$ & +255 & sol. & & & $\begin{array}{l}101.6,100.9,100.6 \\
82.1,81.9,79.3\end{array}$ & $\mathrm{D}_{2} \mathrm{O} / 70^{\circ} \mathrm{C}$ & 31 \\
\hline isolichenan (Ci-3) & $(1 \rightarrow 3),(1 \rightarrow 4)$ & $(2: 1)$ & linear & 2000 & +264 & sol. & & $5.39,5.44$ & $\begin{array}{l}102.2,101.6,101.3 \\
82.2,81.8,79.2\end{array}$ & $\mathrm{D}_{2} \mathrm{O} / 25^{\circ} \mathrm{C}$ & 20 \\
\hline isolichenan & $(1 \rightarrow 3),(1 \rightarrow 4)$ & $(3: 1)$ & $\begin{array}{l}\text { linear, irregular } \\
\text { distribution of } \\
\text { linkages }\end{array}$ & 294 & +213 & sol. & & & $\begin{array}{l}\text { 101.3, 100.7, 100.6 } \\
100.3,81.4,81.3 \\
80.9,78.4\end{array}$ & $\mathrm{D}_{2} \mathrm{O} / 70^{\circ} \mathrm{C}$ & 48 \\
\hline isolichenan & $(1 \rightarrow 3),(1 \rightarrow 4)$ & $(3.8: 1)$ & $5 \%$ branched at $\mathrm{O} 2$ & & +243 & sol. & & & $\begin{array}{l}101.6,101.0,100.6 \\
82.1,81.9,79.3\end{array}$ & $\mathrm{D}_{2} \mathrm{O} / 70^{\circ} \mathrm{C}$ & 31 \\
\hline $\begin{array}{r}\text { isolichenan } \\
\text { (everniin) }\end{array}$ & $(1 \rightarrow 3),(1 \rightarrow 4)$ & $(4: 1)$ & linear & 26 & +138 & insol. & $\begin{array}{l}925,845 \\
780\end{array}$ & & & & \\
\hline isolichenan & $(1 \rightarrow 3),(1 \rightarrow 4)$ & $(6: 1)$ & incl. $(1 \rightarrow 6)$-linkages & & +152 & insol. & & & & & \\
\hline nigeran type (PC-3) & $(1 \rightarrow 3),(1 \rightarrow 4)$ & $(1: 1)$ & linear & 21 & $+201^{a}$ & insol. & $\begin{array}{l}925,845 \\
780\end{array}$ & & & & \\
\hline “ & $“$ & $“$ & linear & 69 & $+155^{b}$ & insol. & & & $\begin{array}{l}100.2,99.3,82.5 \\
78.8,60.4,59.9\end{array}$ & $\begin{array}{l}\text { DMSO- } d_{6} / \\
70{ }^{\circ} \mathrm{C}\end{array}$ & 48 \\
\hline nigeran/isolichenan & $(1 \rightarrow 3),(1 \rightarrow 4)$ & $(1.2: 1)$ & linear & & & insol. & & & & & \\
\hline nigeran type & $(1 \rightarrow 3),(1 \rightarrow 4)$ & $(1: 1)$ & incl. $(1 \rightarrow 2)$-linkages & & +217 & insol. & & & & & \\
\hline acroscyphan & $(1 \rightarrow 3),(1 \rightarrow 4)$ & $(2: 3)$ & $\begin{array}{l}\text { incl. } 6 \%(1 \rightarrow 6) \text { - } \\
\text { linkages }\end{array}$ & & +176 & insol. & 845 & & & & \\
\hline acroscyphan-type & $(1 \rightarrow 3),(1 \rightarrow 4)$ & $(2: 5)$ & $\begin{array}{l}\text { ca. } 3 \% \text { branched at } \\
\text { O3 }\end{array}$ & 24 & +233 & sol. & & & & & \\
\hline
\end{tabular}

a $2 \mathrm{~N} \mathrm{NaOH} \quad$ b $1 \% \mathrm{NaOH}$.

Table 4 Galactomannans from lichens - structural characteristics and analytical data (see Table $\mathbf{1}$ for further references)

\begin{tabular}{|c|c|c|c|c|c|c|c|c|c|}
\hline Structural type & $\begin{array}{l}\text { Linkages } \\
\text { in main chain }\end{array}$ & $\begin{array}{l}\text { Ratio: } \\
\text { Man/Gal/Glc }\end{array}$ & Side chains or substitution & $\begin{array}{l}M_{r} \\
\text { in } k D\end{array}$ & $\begin{array}{l}{[\alpha]_{\mathrm{D}}} \\
\mathrm{deg}\end{array}$ & $\begin{array}{l}\text { Sol. in } \\
\text { cold } \mathrm{H}_{2} \mathrm{O}\end{array}$ & Anomeric ${ }^{13} \mathrm{C}$ NMR shifts & $\begin{array}{l}\text { NMR } \\
\text { sol/temp }\end{array}$ & Ref. \\
\hline $\begin{array}{l}\text { Galactoglucomannans } \\
\text { in general } \\
\text { (have been isolated } \\
\text { from at least } 24 \\
\text { species of lichens) }\end{array}$ & $\begin{array}{l}(1 \rightarrow 6) \text {-linked } \\
\alpha \text {-D-Manp }\end{array}$ & $\begin{array}{l}\text { variable, } \\
\text { Man or Gal } \\
\text { are always } \\
\text { dominating }\end{array}$ & $\begin{array}{l}\text { different pattern of } \\
\text { substitution mainly at } \\
\text { O2 or } 04 \text {, by units of } \\
\alpha \text { - or } \beta \text {-Galp or } \alpha \text {-Man } p \\
\text { or Glcp, more rarely by } \\
\beta \text {-Galf or } \alpha \text {-Manf }\end{array}$ & $\begin{array}{l}\text { ca. } 2000 \text { was } \\
\text { recently } \\
\text { published for } \\
\text { two glycans } \\
\text { from } \\
\text { Cladonia sp. }\end{array}$ & $\begin{array}{l}+20 \text { to } \\
+115\end{array}$ & sol. & $\begin{array}{l}109.5(\beta \text {-Galf- }(1 \rightarrow 4)) \\
104.7(\beta \text {-Galp- }(1 \rightarrow 4) \text { and } \\
\beta \text {-Glcp- }(1 \rightarrow 4)) \\
103.7(\alpha \text {-Manp- }(1 \rightarrow 2)-\alpha- \\
\text { D-Manp) } \\
102.8(\alpha \text {-Galp- }(1 \rightarrow 2)) \\
102.2(\alpha \text {-Manp- }(1 \rightarrow 2)-\alpha- \\
\text { Manp- }(1 \rightarrow 2)) \\
101.0 \text { (unsub. }(1 \rightarrow 6)- \\
\text { linked } \alpha \text {-Manp units) } \\
99.9 \text { (sub. at O2, }(1 \rightarrow 6)- \\
\text { linked } \alpha \text {-Manp units) }\end{array}$ & $\mathrm{D}_{2} \mathrm{O} / 70{ }^{\circ} \mathrm{C}$ & 2,4 \\
\hline CL-galactomannan & $\begin{array}{l}(1 \rightarrow 6) \text {-linked } \\
\alpha \text {-D-Manp }\end{array}$ & $82: 18: 00$ & $\begin{array}{l}\text { partly sub. at O4 and/or } \\
\text { O2 by end units of } \beta \text {-Galp } \\
(19 \%), \alpha \text {-Manp (39\%) and } \\
\beta \text {-Galf }(0.3 \%)\end{array}$ & 140 & +40 & sol. & $\begin{array}{l}\text { 109.2, 107.1, 104.7, } \\
\text { 104.0, 103.5, 102.0 } \\
100.4,99.5\end{array}$ & $\mathrm{D}_{2} \mathrm{O} / 30^{\circ} \mathrm{C}$ & 23 \\
\hline StR-galactomannan & $\begin{array}{l}(1 \rightarrow 6) \text {-linked } \\
\alpha \text {-D-Manp }\end{array}$ & $57: 43: 00$ & $\begin{array}{l}\text { partly sub. at } \mathrm{O} 4 \text { and/or } \\
\mathrm{O} 2 \text { by end units of } \beta \text {-Galp } \\
\text { and } \alpha \text {-Manp }\end{array}$ & & +73 & & & & 53 \\
\hline TI-glucomannan & $\begin{array}{l}(1 \rightarrow 6) \text {-linked } \\
\alpha \text {-D-Manp }\end{array}$ & $93: 00: 07$ & $\begin{array}{l}\text { partly sub. at } \mathrm{O} 2 \text { with } \\
\alpha \text {-D-Manp and a small } \\
\text { amount of } \alpha \text {-D-Glcp }\end{array}$ & ca. 100 & +74 & sol. & & & \\
\hline CL-glucomannan & \multicolumn{2}{|c|}{ not determined $35: 00: 65$} & not determined & & & sol. & & & 23 \\
\hline
\end{tabular}

$\beta$-D-galactofuranosyl units (22). A third heteroglycan was isolated from Collema leptosporum (23) but the structure was not characterized except for the monosaccharide composition which revealed that this glycan, in contrast to the other complex heteroglycans, contains no rhamnosyl units.

$\mathrm{Ki}-\mathrm{M}-7$ is a galactomannan isolated from the alkali extract of Cetraria islandica by Ingólfsdottir et al. (24). This galactomannan is grouped with the complex heteroglycans as it contains a small proportion of rhamnosyl units (Table $\mathbf{5}$ ).

\section{Biological Activity}

Polysaccharides from plants and other natural sources have long been known to exert antitumour, immunomodulatory, anticoagulent, and other types of biological activity (57-59). Research over the last 30 years, much of which has been performed in Japan, has shown lichen polysaccharides to possess similar types of biological activity, whilst having a low toxicity level. 
Table 5 Complex heteroglycans from lichens - structural characteristics and analytical data

\begin{tabular}{|c|c|c|c|c|c|c|c|c|}
\hline Structural type & $\begin{array}{l}\text { Monosaccharide comp. } \\
\text { ratios in parantheses }\end{array}$ & Main structural characteristics & $\begin{array}{l}M_{r} \\
k D\end{array}$ & $\begin{array}{l}{[\alpha]_{\mathrm{D}}} \\
\operatorname{deg}\end{array}$ & $\begin{array}{l}\text { Sol. in } \\
\text { cold } \mathrm{H}_{2} \mathrm{O}\end{array}$ & $\begin{array}{l}\text { Anomeric and other } \\
\text { characteristic }{ }^{13} \mathrm{C} \text { NMR shifts }\end{array}$ & $\begin{array}{l}\text { NMR } \\
\text { sol/temp }\end{array}$ & Ref. \\
\hline Thamnolan & $\begin{array}{l}\text { Gal: Rha: Glc:Xyl: Man } \\
(40: 31: 13: 10: 6)\end{array}$ & $\begin{array}{l}\text { Dominated by a }(1 \rightarrow 3) \text {-linked } \beta \text {-D- } \\
\text { Galf with sidechains in position } 6 \text { for } \\
\text { about } 7 \% \text { of the units, and an } \\
(1 \rightarrow 2) \text {-linked } \alpha \text {-L-Rhap with branches } \\
\text { on either } C 3 \text { or } C 4 \text {. Xyl is only } \\
\text { present as a terminal unit and after } \\
\text { partial hydrolysis, the trisacch. } \\
\text { XylGlcGlc was detected. }\end{array}$ & 1450 & $-63^{b}$ & sol. & $\begin{array}{l}109.3 \text { (C1 in Galf) } \\
19.0 \text { (C6-Me in Rhap) peeks } \\
\text { around } 102 \text { (C1 in Rhap) }\end{array}$ & $\mathrm{D}_{2} \mathrm{O} / 25^{\circ} \mathrm{C}$ & +6 \\
\hline CP-heteroglycan & $\begin{array}{l}\text { Gal: Rha: Glc: Xyl: Man: } \\
\text { Fuc } \\
(17: 4: 8: 32: 29: 10)\end{array}$ & $\begin{array}{l}\text { A main chain dominated by }(1 \rightarrow 3) \text { - } \\
\text { linked } \alpha \text {-D-Manp, monosub. at O4 } \\
(10 \%) \text { or disub. at } \mathrm{O} 2 \text { and } \mathrm{O} 4(10 \%) \\
\text { with } \beta \text {-D-Xylp }\end{array}$ & & +25 & sol. & $\begin{array}{l}105.2(C 1 \text { in } \beta \text {-D-Xylp) } \\
103.0,100.9,99.7,80.1,17.3\end{array}$ & $\mathrm{D}_{2} \mathrm{O} / 70^{\circ} \mathrm{C}$ & 7 \\
\hline CL-heteroglycan & $\begin{array}{l}\text { Gal: Glc: Xyl: Man } \\
(24: 27: 18: 31)\end{array}$ & Not described further & & & sol. & & & 23 \\
\hline Ki-M-7 & $\begin{array}{l}\text { Gal: Man: Rha } \\
(57: 39: 4)\end{array}$ & $\begin{array}{l}\text { Composed of two blocks } \\
\text { Firstly: }(1 \rightarrow 6) \text {-linked } \alpha \text {-D-Manp units } \\
\text { partly sub. at } \mathrm{O} 2 \text { or } \mathrm{O} 4 \text {. } \\
\text { Secondly: }(1 \rightarrow 6) \text {-linked } \alpha \text {-D-Galf } \\
\text { units, partly } 2,4 \text {-di-O-sub. } \\
\text { Terminal units of } \alpha \text {-D-Galp or } \\
\beta \text {-D-Galf. }\end{array}$ & 18 & +112 & sol. & $\begin{array}{l}107.9 \text { (C1 in } \beta \text {-D-Gal-f) } \\
103.1 \text { (C1 in } \alpha \text {-D-Galp) } \\
101.4 \text { (C1 in } 1,6-\alpha \text {-D-manp) } \\
99.9 \text { (C1 in } 1,4,6 \text { - } \alpha \text {-D-Manp) } \\
99.3 \text { (C1 in } 1,6-\alpha \text {-D-Galp) } \\
99.0 \text { (C1 in } 1,2,4,6-\alpha \text {-D-Galp) }\end{array}$ & $\mathrm{D}_{2} \mathrm{O} / 25^{\circ} \mathrm{C}$ & 24 \\
\hline
\end{tabular}

a ${ }^{1} \mathrm{H}-\mathrm{NMR}$ shifts for thamnolan: $5.22 \mathrm{U}<2.0 \mathrm{~Hz}, \mathrm{H} 1$ in Galf), 1.32 (s, C6-Me in Rhap).

${ }^{b}$ Not previously published. Measured in $\mathrm{D}_{2} \mathrm{O}$ at $23^{\circ} \mathrm{C}(\mathrm{c} 1.0 \mathrm{mg})$.

\section{Antitumour and immunological activity}

Japanese scientists have studied lichen polysaccharides extensively for non-cytotoxic, host-mediated antitumour activity. In the first of these investigations (60), crude polysaccharide fractions from 9 lichen species, obtained as ethanol precipitates from aqueous extracts, were investigated for activity against subcutaneously implanted sarcoma-180 ascites tumour in mice. The polysaccharides were administered (200 mg/kg) intraperitoneally daily for 10 days starting 24 hours after tumour implantation. After 5 weeks the average tumour weights in the treated and control groups were compared. Many of the polysaccharide fractions suppressed tumour growth, often with a very high rate of complete regression.

Further fractionation of active polysaccharide fractions showed both isolichenan-rich and lichenan-rich fractions (Tables 2 and 3 ) from Cetraria islandica var. orientalis to be highly active. No direct cytocidal activity was detected and the effects were proposed to be host-mediated. Partially acylated $\beta$ $(1 \rightarrow 6)$ pustulan-type glucans (Table 2 ) were obtained through further fractionation of active fractions from Gyrophora esculenta (GE-3) and Lasallia papulosa (44).

The acyl group was later identified as $O$-acetyl attached in the 3 -position of approximately $10 \%$ of the glucose units (41), this being the first example of acetylated polysaccharides isolated from lichens. Structure-activity investigations revealed that deacetylation reduced the antitumour activity whereas replacement of 0 -acetyl groups by 0 -methyl groups, or complete acetylation of the glucan, caused total loss of activity (41).

Further investigations by the Japanese team headed by Nishikawa involved the isolation of highly active, partially acylated pustulan-type glucans from Umbilicaria species (45), shown to have a close resemblance to GE-3. Furthermore, a highly ac- tive $\beta$-glucan (UR-1-1) identified as lichenan was isolated from Usnea rubescens, an active GE-3-type glucan (L-Pe-1-1) was isolated from Lasallia pensylvanica and moderately active heteropolysaccharides consisting chiefly of mannose, galactose, and glucose units were found in Cladonia species (28).

In order to establish whether the antitumour activity of GE-3 and UR-1-1 was achieved through stimulation of immune responses, the polysaccharides were subjected to testing in the in vivo carbon clearance test. Intraperitoneal administration of GE-3 to mice at a dose of $100 \mathrm{mg} / \mathrm{kg}$ resulted in a significant increase in the rate of colloidal carbon elimination, suggesting significant activation of the reticuloendothelial system (61). No activity was observed for the lichenan UR-1-1. Lauroyl derivatives of GE-3 were less effective, and a cold-water soluble carboxymethyl derivative was inactive.

Two isolichenan-type polysaccharides, EP-3 and EP-6, differing in the ratio of $(1 \rightarrow 3)-,(1 \rightarrow 4)$-linkages, in addition to a lichenan (EP-7) were isolated from a crude extract of Evernia prunastri (Table 1) which had shown activity against sarcoma-180 (17). Testing of the purified polysaccharides revealed that the isolichenans were inactive while EP-7 showed significant growth-inhibitory effects. Inactive $\alpha$-glucans were isolated from active crude polysaccharide fractions from Acroscyphus sphaerophoroides, Alectoria sulcata, and Alectoria sarmentosa, while active lichenan was isolated from both Alectoria species.

Of the water-soluble polysaccharides from Lobaria species (Stictaceae) showing antitumour activity against transplanted sarcoma 180, two glycopeptides (LOF-1, LOF-2) were identified from $L$. orientalis (62). The main carbohydrate components of LOF- 1 were shown to be a $(1 \rightarrow 6)$-glucan and a $(1 \rightarrow 3)$ mannan, linkage to the peptide moiety occurring through $O$ glycosyl linkages with serine and threonine. An inhibition of $81.6 \%$ was exhibited by LOF- 1 at a dose of $10 \mathrm{mg} / \mathrm{kg}$. 
Lichenan and pustulan were chosen as representatives of polysaccharides active against allogenic tumours (e.g., sarcoma 180) to see whether they would also be active against syngeneic tumours in mice. Results showed that pustulan was active against three types of syngeneic tumours at daily doses of $25-75 \mathrm{mg} / \mathrm{kg}$, suggesting immuno-mediated activity, whereas lichenan was inactive (63).

An increase in $\alpha_{1}$-acid glycoprotein $\left(\alpha_{1}\right.$-AG) levels in the serum of ascites tumour-bearing mice treated with lichen polysaccharides was later observed (64). It was suggested that this might be linked to the antitumour activity of the polysaccharides as purified $\alpha_{1}$-AG inhibited the growth of tumour cells in vitro. Lichenan, GE-3, and urea-treated GE-3 (UGE-3) all caused pathological changes to the liver and spleen, liver necrosis becoming evident soon after i.p. administration. Leukopenia was further induced, followed by leukocytosis. Earlier (65) it had been observed that the liver of mice receiving injections of $\beta$-glucans from lichens became enlarged and multifocal mesenchymal cell accumulation occurred, the severity and duration being dose-dependent. No liver changes were observed on administration of $\alpha$-glucans such as isolichenan. When pustulan and lichenan were tested for activity against syngeneic tumours as referred to above (63), the liver and spleen weights of mice treated with pustulan increased considerably more than in those treated with lichenan, the effects of pustulan being correlated with an increase in number and activity of macrophages.

The first report (24) of a chromatographically purified polysaccharide from lichens being tested for immunostimulating activity was that of the galactomannan Ki-M-7 (Table 5). The polysaccharide $(100 \mu \mathrm{g} / \mathrm{ml})$, which was shown to be free of LPS contamination, showed enhancement of granulocytic phagocytosis amounting to $68 \%$ in an in vitro phagocytosis assay performed with human granulocytes. When tested for reticuloendothelial phagocytic activity in the in vivo carbon clearance test, a significant increase occurred in the rate of colloidal carbon elimination (24).

As the immunologically active $\mathrm{Ki}-\mathrm{M}-7$ was isolated from an alkali extract, an investigation was undertaken to determine whether polysaccharides extractable with hot water, i.e., constituents of traditional preparations made by boiling the lichen in water, also had immunomodulating properties (66) and might substantiate to some extent pharmacological claims for the plant. Polysaccharides from a hot aqueous extract of Iceland moss were fractionated by ethanol precipitation and ion-exchange chromatography. Several of the major fractions exerted significant in vitro anti-complementary activity and pronounced enhancement of granulocytic phagocytosis. All fractions were subjected to affinity chromatography prior to testing to remove any trace of potential endotoxin impurities.

Further purification of the active polysaccharide fractions led to the isolation of a homogenic cold-water soluble isolichenan-type $\alpha$-glucan, Ci-3 (Table 3). Results of in vitro testing of $\mathrm{Ci}-3$ for phagocytic and anti-complementary activity showed that, at concentrations of $100 \mu \mathrm{g} / \mathrm{ml}, \mathrm{Ci}-3$ stimulated granulocytic phagocytosis about $50 \%$ compared with stimulation by fMLP set as $100 \%$ and reduced complementary-induced hemolysis by about $80 \%$ (20).
At concentrations of $100 \mu \mathrm{g} / \mathrm{ml}$ and $1000 \mu \mathrm{g} / \mathrm{ml}$, the complex and novel polysaccharide, thamnolan (Table 5), stimulated in vitro granulocytic phagocytosis about $36 \%$ and $91 \%$, respectively, compared with stimulation by fMLP set as $100 \%$ (6). The polysaccharide was free from LPS contamination. This activity is comparable to that of $\mathrm{Ci}-3$ (20), but a little less than that reported for Ki-M-7 (24). Results of in vitro anti-complementary testing show that at concentrations of $100 \mu \mathrm{g} / \mathrm{ml}$, thamnolan reduces complementary-induced hemolysis about $90 \%(6)$.

\section{Cytotoxicity}

In addition to non-cytotoxic antitumour activity as referred to above, lichen $\alpha$-glucans have been shown to exhibit cytotoxicity. An $\alpha-(1 \rightarrow 3)-(1-4)$-glucan obtained from Ramalina celastri as well as its sulfated derivative showed cytotoxic activity against HeLa cells (67). Signs of cell death induced by apoptosis were seen.

\section{Antiviral activity}

Lichenan from Iceland moss exhibited antiviral activity against the following viruses which had been mechanically transmitted into Nicotiana species: tobacco mosaic- and etchviruses (TMV, TEV), potato viruses X and Y (PVX, PVY), as well as cucumber mosaic virus (CMV) (68). Partly hydrolysed lichenan with different degrees of polymerisation (6-30, 30 $60,60-90,>190$ ) was equally effective in reducing the number of local (TMV) and systemic (PV4) infections compared to the native glucan. Other mixed-linkage $\beta$-glucans, including schizophyllan and pachyman from fungi, and laminaran from algae, were less active than lichenan. In contrast, pustulan as well as $\alpha$-glucans were ineffective. The mechanism of action of lichenan is not clear, but results indicated that early events of viral replication were affected (69).

\section{Hippocampal potentiation}

In studies on the effects of glucans on hippocampal synaptic plasticity in rodents, isolichenan from Parmelia caperata, administered orally and intravenously, enhanced the electrophysiological model of spatial memory in rats, i.e., the formation of hippocampal long-term potentiation (39). Isolichenan from $\mathrm{Ce}$ trariella islandica, on i.v. administration, significantly enhanced short-term potentiation evoked by a subthreshold tetanus, without any effect on basal evoked synaptic potential (70). The $\beta$-glucans, lichenan and GE-3, were inactive. Orally administered isolichenan was further shown to improve memory acquisition in mice, the learning ability of which had been impaired by ethanol, as well as in rats in which memory impairment had been induced by beta-amyloid peptide (70), (71).

\section{Biological activity of polysaccharide derivatives}

Derivatives of the linear $\beta$-D-glucans which had proven particularly effective against sarcoma-180, i.e., GE-3 and UR-1-1, were prepared and evaluated for antitumour activity (72). Results showed that treatment with urea caused no reduction in activity whereas on carboxymethylation, the antitumour activity was greatly reduced. Lauroyl derivatives with different degrees of substitution were also prepared from GE-3. Derivatives with lauroyl contents less than $3.3 \%$ exhibited strong an- 
titumour activity, while the more highly esterified products were inactive.

A sulfate derivative, GE-3-S, prepared by chlorosulfonic acid treatment of GE-3 has been shown to inhibit the replication of human immunodeficiency virus (HIV) in vitro (73). GE-3-S inhibited the cytopathic effect of HIV and suppressed HIV-antigen expression in Molt-4 cells without inhibiting HIV-reverse transcriptase. Sulfate derivatives of lichenan from Cetraria islandica and PC-3 from Parmelia caperata were inactive against HIV as were the unsulfated counterparts.

As referred to above, cytotoxic activity has been demonstrated by a sulfated derivative of an $\alpha$-glucan from Ramalina celastri.

\section{Discussion and Conclusion}

By studying Table 1, a pattern of distribution of several lichen polysaccharide structural types can be observed for the three most frequently studied lichen families. The glucan pustulan is characteristic for Umbilicariaceae, lichenan-type glucans are the only $\beta$-glucans found in Parmeliaceae, and the only $\alpha$ glucan isolated from Cladoniaceae is of the nigeran type. Thus, polysaccharides from lichens such as pustulan and lichenan, have been suggested to be of taxonomic importance at genus and family level (2), (8). Chemotypes of lichen galactomannans have also been considered as an aid for classification and identification of lichens by analysis of the anomeric region of their ${ }^{13} \mathrm{C}-\mathrm{NMR}$ spectra (2), (9).

It is exciting to know that, even though only a fraction of the world's lichen species has been investigated for polysaccharide constituents, unusual structures have already emerged. The recently investigated Thamnolia subuliformis belonging to Lichen imperfecti has been shown to contain a water-soluble heteroglycan, thamnolan, with a novel kind of structure not described earlier, either from lichens, fungi, bacteria or plants (6). Thamnolan has been shown to be immunologically active but remains to be studied for further biological activity.

Polysaccharides from lichens have shown various types of biological activity such as potent antitumour activity, general stimulating activity on the unspecific immune system, antiviral activity and recently memory enhancing effects. In some cases activity has been improved by chemical modification.

The most active antitumour lichen polysaccharides on i.p. administration to mice appear to be $(1 \rightarrow 3)-\beta$-glucans. This is perhaps not surprising, as $(1 \rightarrow 3)-\beta$-D-glucans from other sources have been found effective against allogeneic, syngeneic and autochthonous tumours (74). Antitumour activity of lichen polysaccharides was initially thought to be host-mediated, but this has not been confirmed, $c f$. stimulation of the reticuloendothelial system in mice is only exhibited by pustulan-type polysaccharides but not by lichenans. This might indicate that the mechanism of antitumour activity differs between $\beta$-glucans. The possible contributing role of cytotoxicity to the antitumour activity of lichen polysaccharides should not be dismissed, although direct proof of such activity is scarce and limited to in vitro testing.

The importance of the three-dimensional structure of $\beta$-glucans for antitumour activity is well established and has been demonstrated for lentinan, a $(1 \rightarrow 3)-\beta$-glucan from the fungus Lentinus edodes, which has been used clinically for adjuvant cancer therapy in Japan (75). It can be expected that the same applies for other $(1 \rightarrow 3)$ - $\beta$-glucans including the lichen polysaccharides.

Immunomodulating effects, i.e., increased phagocytic activity as well as anti-complementary activity have been confirmed for chromatographically purified lichen polysaccharides, namely an $\alpha$-glucan, galactomannan and rhamnogalactan. Taking into account the use of lentinan and other immunologically active polysaccharides in adjuvant cancer therapy (75), it is worthwhile to study in more detail the in vivo immunological activity of these and other lichen polysaccharides.

Although studies of antiviral activity of lichen polysaccharides are limited, it is noteworthy to observe the difference in antiviral effects expressed by different types of glucans. Noteworthy also is the fact that similar antiviral effects are expressed by lichenans of differing degrees of polymerisation.

The effects of isolichenan on hippocampal function certainly deserve further attention, not least in light of the proposed connection of increased density beta amyloid protein in deterioration associated with Alzheimer's disease.

In view of the diverse biological activity expressed by lichen polysaccharides in limited studies, it seems likely that therapeutic effects claimed from the use of certain lichens, such as Cetraria islandica, Lobaria pulmonaria, and Umbilicaria species, can be in part attributed to the polysaccharides. Lichen polysaccharides definitely deserve further study with regard to biological activity, including studies into mechanism of action and structure-activity relationships. Other lichen species should be investigated, both as a potential source of new chemical structures and biological activity.

\section{Acknowledgements}

The authors thank S. Baldursdottir M.Sc. for taxonomical assistance in the preparation of Table 1. A supporting grant from University of Iceland Research Fund, is gratefully acknowledged.

\section{References}

${ }^{1}$ Huneck S, Yoshimura I. Identification of Lichen Substances. Berlin: Springer Verlag, 1996

${ }^{2}$ Gorin PAJ, Baron M, Silva MLC, Teixeira AZA, Iacomini M. Lichen carbohydrates. Ciencia e Cultura (Journal of the Brazilian Association for the Advancement of Science) 1993; 45: 27-36

${ }^{3}$ Barreto-Bergter E. Chemical Structure, Immunology and Application of Polysaccharides of Fungi and Lichens. In: Atta-ur-Rahman, editor. Studies in Natural Products Chemistry Vol. 5, Structure Elucidation (Part B). Amsterdam: Elsevier, 1989: 275-340

${ }^{4}$ Gorin PAJ, Baron M, Iacomini M. Storage Products of Lichens. In: Galun M, editor. CRC Handbook of Lichenology Vol. 3. Florida: CRC Press, 1988: 9-23

${ }^{5}$ Gorin PAJ, Barreto-Bergter E. The Chemistry of Polysaccharides of Fungi and Lichens. In: Aspinall GO, editor. The Polysaccharides Vol. 2. New York: Academic Press, 1983: 389-94

${ }^{6}$ Olafsdottir ES, Omarsdottir S, Smestad Paulsen B, Jurcic K, Wagner $\mathrm{H}$. Rhamnopyranosylgalactofuranan, a new immunologically 
active polysaccharide from Thamnolia subuliformis. Phytomedicine 1999; 6 (4): $273-9$

${ }^{7}$ Iacomini M, Zanin SMW, Fontana JD. Isolation and characterization of $\beta$-D-glucan, heteropolysaccharide, and trehalose components of the Basidiomycetous lichen Cora pavonia. Carbohydrate Research 1987; 168: 55-65

${ }^{8}$ Common RS. The distribution and taxonomic significance of lichenan and isolichenan in the Parmeliaceae (lichenized Ascomycotina), as determined by iodine reactions. I. Introduction and methods. II. The genus Alectoria and associated taxa. Mycotaxon 1991; XLI: $67-112$

${ }^{9}$ Teixeira AZA, Iacomini M, Gorin PAJ. Chemotypes of mannosecontaining polysaccharides of lichen mycobionts: a possible aid in classification and identification. Carbohydrate Research 1995; 266: $309-14$

${ }^{10}$ Takahashi K, Takeda T, Shibata S. Polysaccharides of lichen symbionts. Chemical \& Pharmaceutical Bulletin 1979; 27 (1): 238 41

${ }^{11}$ Konig J, Pevelung E. Cell wall of the phycobiont Trebouxia and Pseudotrebouxia: Constituents and their localization. Lichenologist 1984; 16: 129-44

12 Stone BA, Clarke AE. Chemistry and Biology of (1-3)- $\beta$-Glucans. Victoria, Australia: La Trobe University Press, 1992: 60-75, $283-358$

${ }^{13}$ Vartia KO. Antibiotics from Lichens. In: Ahmadjian V, Hale MS, editors. The Lichens. New York: Academic Press, 1973: 547

${ }^{14}$ Ingólfsdóttir K. Bioactive Compounds in Iceland Moss. In: Smestad-Paulsen B, editor. Bioactive Carbohydrate Polymers, Proceedings Phytochemical Society of Europe. Dordrecht: Kluwer Academic Publishers, 2000: 25-36

${ }^{15}$ Baron M, Iacomini M, Fanta E, Gorin PAJ. Galactomannan, lichenan and isolichenan from the polysaccharide-rich lichen Newropogon aurantiago-ater. Phytochemistry 1991; 30: 3125-6

${ }^{16}$ Smith AL. Lichens. Cambridge University Press, 1921

${ }^{17}$ Takeda T, Funatsu M, Shibata S, Fukuoka F. Polysaccharides of lichens and fungi V. Antitumor active polysaccharides of Evernia, pacroscyphus and Alectoria species. Chemical \& Pharmaceutical Bulletin 1972; 20: 2445-9

${ }^{18}$ Chanda NB, Hirst EL, Manners DJ. A comparison of isolichenin and lichenin from Iceland moss (Cetraria islandica). Journal of Chemical Society 1957; $1951-8$

${ }^{19}$ Peat S, Whelan WJ, Turvey JR, Morgan K. The structure of isolichenin. Journal of Chemical Society 1961; 623-9

${ }^{20}$ Olafsdottir ES, Ingolfsdottir K, Barsett H, Smestad Paulsen B, Jurcic $\mathrm{K}$, Wagner $\mathrm{H}$. Immunologically active $(1 \rightarrow 3)-(1-A)-\alpha$-D-glucan from Cetraria islandica. Phytomedicine 1999; 6 (1): $33-9$

${ }^{21}$ Ulander A, Tollens B. Untersuchungen über die Kohlenhydrate der Flechten. Berichte der deutschen chemischen Gesellschaft 1906; 39: 401

22 Preston JF, Gander JE. Isolation and partial characterization of the extracellular polysaccharides of Penicillium charlesii. Archives of Biochemistry and Biophysics 1968; 124: 504-12

${ }^{23}$ Prado SRT, Gorin PAJ, Stuelp PM, Honda NK, Iacomini M. An unusual juxtaposition of polysaccharide components of Collema leptosporum. Carbohydrate Polymers 1999; 40: $271-6$

${ }^{24}$ Ingolfsdottir K, Jurcic K, Fischer B, Wagner H. Immunologically active polysaccharide from Cetraria islandica. Planta Medica 1994; 60: $527-31$

${ }^{25}$ Iacomini M, Schneider CL, Gorin PAJ. Comparative studies on the polysaccharides of Cladonia alphestris (Reindeer moss), Cladonia confusa and Cladonia amaurocraea. Carbohydrate Research 1985; 142: 237-51

${ }^{26}$ Shibata S. Polysaccharides of lichens. Journal of the National Science Council of Sri Lanka 1973; 1: 183-8

${ }^{27}$ Woranovicz-Barreira SM, Gorin PAJ, Sassaki GL, Tischer CA, Ahti $\mathrm{T}$, Iacomini M. Chemotyping glucans from lichens of the genus Cladonia. Phytochemistry 1999; 52: 1069-74
${ }^{28}$ Nishikawa Y, Ohki K, Takahashi K, Kurono G, Fukuoka F, Emori M. Studies on the water soluble constituents of lichens. II. Antitumor polysaccharides of Lasallia, Usnea and Cladonia Species. Chemical \& Pharmaceutical Bulletin 1974; 22: 2692-702

${ }^{29}$ Woranovicz-Barreira SM, Pinto BM, Gorin PAJ, Iacomini M. Novel structures in galactomannans of the lichens Cladonia substellata and Cladonia ibitipocae: Significance as chemotypes. Phytochemistry 1999; 51 : 395-402

${ }^{30}$ Gorshkova RP, Nazarenko EL, Zubkov VA, Stepanenko LS, Isakov VV. Structural study of polysaccharides from Cetraria cucullata and Cetraria islandica lichens. Russian Journal of Bioorganic Chemistry 1997; 23 (2): $122-5$

${ }^{31}$ Gorin PA, Iacomini M. Polysaccharides of the lichens Cetraria islandica and Ramalina usnea. Carbohydr. Res. 1984; 128: 119-32

${ }^{32}$ Mittal OP, Neelakantan S, Seshadri TR. Chemical investigations of Indian lichens. Part XIV. Journal of Scientific and Industrial Research (India) 1952; 11B: 386-7

${ }^{33}$ Yokota I, Shibata S, Saito H. A ${ }^{13}$ C-n.m.r. analysis of linkages in lichen polysaccharides: an approach to chemical taxonomy of lichens. Carbohydrate Research 1979; 69: $252-8$

${ }^{34}$ Teixeira AZA, Iacomini M, Gorin PAJ. An unusual glucomannan from Tornabenia incarnata. Phytochemistry 1992; 31: 3467-70

${ }^{35}$ Micovic VM, Hranisavljevic-Jakovljevic M, Miljkovic-Stojanovic J. Structural study of polysaccharides from the oak lichen Evernia prunastri (L.). Ach. Carbohydrate Research 1969; 10: 525-33

${ }^{36}$ Iacomini M, Gorin PAJ, Baron M, Tulloch AP, Mazurek M. Novel D-glucans obtained by dimethyl sulphoxide extraction of the lichens Letharia vulpina, Actinogyra muehlenbergii and an Usnea sp. Carbohydrate Research 1988; 176: 117-26

${ }^{37}$ Gorin PAJ, Iacomini M. Structural diversity of galactomannan components isolated from lichens having Ascomycetous mycosymbionts. Carbohydrate Research 1985; 142: 253-67

${ }^{38}$ Takeda T, Nishikawa Y, Shibata S. A new $\alpha$-glucan from the lichen Parmelia caperata (L.). Ach. Chemical \& Pharmaceutical Bulletin 1970; 18 (5): 1074-5

${ }^{39}$ Smriga M, Saito H, Shibata S, Narui T, Okuyama T, Nishiyama N. PC-2, linear homoglucan with $\alpha$-linkages, peripherally enhanches the hippocampal long-term potentiation. Pharmaceutical Research 1996; 13 (9): 1322-6

40 Olafsdottir ES. Unpublished results.

${ }^{41}$ Nishikawa Y, Takeda T, Shibata S, Fukuoka F. Polysaccharides in lichens and fungi III. Further investigation on the structures and the antitumor activity of the polysaccharides from Gyrophora esculenta Miyoshi and Lasailla papulosa (Ach.) Llano. Chemical \& Pharmaceutical Bulletin 1969; 17: 1910-6

42 Periera EC, Nascimento SC, Lima RC, Silva NH, Oliveira AF, Bandeira E, Boitard M, Beriel H, Vicente C, Legaz ME. Analysis of Usnea fasciata crude extracts with antineoplastic activity. Tokai Journal of Experimental and Clinical Medicine 1994; 19: 47-52

${ }^{43}$ Mittal OP, Seshadri TR. Chemical investigation of Indian lichens XVI. Purification and composition of lichenin and isolichenin from Indian lichens. Journal of Scientific and Industrial Research (India) 1954; 13B: $244-5$

${ }^{44}$ Shibata S, Nishikawa Y, Takeda T, Tanaka M, Fukuoka F, Nakanishi M. Studies on the chemical structures of the new glucans isolated from Gyrophora esculenta Miyoshi and Lasailla papulosa (Ach.) Llano and their inhibiting effect on implanted sarcoma 180 in mice. Chemical \& Pharmaceutical Bulletin 1968; 16: $1639-41$

${ }^{45}$ Nishikawa Y, Tanaka M, Shibata S, Fukooka F. Polysaccharides of lichens and fungi IV. Antitumor active $O$-acetylated pustulantype glucans from lichens of Umbilicaria species. Chemical \& Pharmaceutical Bulletin 1970; 18: $1431-4$

${ }^{46}$ Lindberg B, McPherson J. Studies on the chemistry of lichens VI. The structure of pustulan. Acta Chemica Scandinavica 1954; 8 : 985 
${ }^{47}$ Kjölberg O, Kvernheim AL. Studies on the polysaccharides III. The structure of alkali-soluble polysaccharides in Umbilicaria pustulata (L.) Hoffm. and Umbilicaria spodochroa (Arch.) Hoffm. Acta Chemica Scandinavica 1989; 43: 280-5

${ }^{48}$ Stuelp PM, Carneiro Leao AMA, Gorin PAJ, Iacomini M. The glucans of Ramalina celastri: Relation with chemotypes of other lichens. Carbohydrate Research 1999; 40: 101-6

${ }^{49}$ Miceno AM, Gorin PAJ, Iacomini M. Galactomannan and isolichenan components of the carbohydrate-rich lichen Ramalina ecklonii. Agricultural and Biological Chemistry 1991; 55: 1391 2

${ }^{50}$ Takahashi K, Kon K, Yokota I, Shibata S. Chemotaxonomic studies on the polysaccharides of lichens. Polysaccharides of Stereocaulaceous lichens. Carbohydrate Research 1981; 89: 166-73

51 Yokota I, Shibata S. A polysaccharide of the lichen Stereocaulon japonicum. Chemical \& Pharmaceutical Bulletin 1978; 26: $2668-70$

${ }^{52}$ Hauan E, Kjölberg O. Studies on the polysaccharides of lichens. I. The structure of a water-soluble polysaccharide in Stereocaulon paschale (L.) Fr. Acta Chemica Scandinavica 1971; 25: 2622-8

${ }^{53}$ Baron M, Gorin PAJ, lacomini M. Structural studies on the galactomannan isolated from the lichen Stereocaulon ramulosum. Agricultural and Biological Chemistry 1989; 53: $1751-8$

${ }^{54}$ Baron M, Gorin PAJ, Iacomini M. Isolation and identification of a linear $(1 \rightarrow 3)$-linked $\beta$-D-glucan and other carbohydrate components of the lichen Stereocaulon ramulosum (Sw.) Rausch. Carbohydrate Research 1988; 177: 235-9

55 Corradi da Silva MDL, Iacomini M, Jablonski E, Gorin PAJ. Carbohydrate, glycopeptide and protein components of the lichen Sticta sp. and effect of storage. Phytochemistry 1993; 33: 547-52

${ }^{56}$ Krämer P, Wincierz U, Grüber G, Tschakert J, Voelter W, Mayer $\mathrm{H}$. Rational approach to fractionation, isolation and characterization of poylsaccharides from the lichen Cetraria islandica. Arzneimittel - Forschung/Drug Research 1995; 45 (I): 726-31

${ }^{57}$ Whistler RL, Bushway AA, Singh PP. Noncytotoxic, antitumour polysaccharides. Advances in Carbohydrate Chemistry and Biochemistry $1976 ; 32$ : $235-75$

${ }^{58}$ Wagner $\mathrm{H}$. Immunomodulatory agents from plants. Progress in Inflammation Research. Parnham M, series editor. Basel: Birkhauser Verlag, 1999

${ }^{59}$ Franz G. Polysaccharides in pharmacy: Current applications and future concepts. Planta Medica 1989; 55: $493-7$

${ }^{60}$ Fukuoka F. et al. Polysaccharides in lichens and fungi. II. Antitumor activities on sarcoma-180 of the polysaccharide preparations from Gyrophora esculenta Miyoshi, Cetraria islandica (L.). Ach. var. Orientalis Asahina, and some other lichens. GANN Japanese Journal of Cancer Research 1968; 59: 421-32

${ }^{61}$ Nishikawa Y, Ohno H. Studies on the water-soluble constituents of lichens. IV. Effect of antitumor lichen-glucans and related derivatives on the phagocytic activity of the reticuloendothelial system in mice. Chemical \& Pharmaceutical Bulletin 1981; 29 (11): $3407-10$

${ }^{62}$ Takahashi K, Takeda T, Shibata S, Inomata M, Fukuoka F. Polysaccharides of lichens and fungi. VI. Antitumour active polysaccharides of lichens of Stictaceae. Chemical \& Pharmaceutical Bulletin 1974; 22 (2): 404-8

${ }^{63}$ Konopa J, Privett OS, Jenkin HM, Goldin A. Polysaccharides as stimulators of nonspecific immunological response against syngeneic tumors in mice. In: Sigienthaler W, Luthy R, editors. Current Chemotherapy: Proceedings of the $10^{\text {th }}$ International Congress of Chemotherapy. Washington D.C.: American Society for Microbiology, 1978: 1095-7

${ }^{64}$ Watanabe M, Iwai K, Shibata S, Takahashi K, Narui T, Tashiro T. Purification and characterization of mouse $\alpha_{1}$-acid glycoprotein and its possible role in the antitumor activity of some lichen polysaccharides. Chemical \& Pharmaceutical Bulletin 1986; 34 (6): $2532-41$
65 Tokuzen R, Nakahara W, Fukuoka F, Shibata S, Nishikawa Y. Liver changes in mice treated with lichen polysaccharides. Toxicology and Applied Pharmacology 1970; 17: 529-37

${ }^{66}$ Ingólfsdóttir K, Jurcic K, Wagner H. Immunomodulating polysaccharides from aqueous extracts of Iceland moss. Phytomedicine 1998; 5 (5): $333-9$

${ }^{67}$ Leao AMAC, Buchi DF, Iacomini M, Gorin PAJ, Oliveira MBM. Cytotoxic effect against HeLA cells of polysaccharides from the lichen Ramalina celastri. Journal of Submicroscopic Cytology and Pathology 1997; 29 (4): $503-9$

${ }^{68}$ Stübler D, Buchenauer $\mathrm{H}$. Antiviral activity of the glucan lichenan (poly- $\beta$ - $(1 \rightarrow 3,1-A)$-D-anhydroglucose). I. Biological activity in tobacco plants. Journal of Phytopathology 1996; 144: $37-43$

${ }^{69}$ Stübler D, Buchenauer $\mathrm{H}$. Antiviral activity of the glucan lichenan (poly- $\beta-(1 \rightarrow 3,1-A)$-D-anhydroglucose). II. Studies on the mode of action. Journal of Phytopathology 1996; 144: 45-52

${ }^{70}$ Smriga M, Chen J, Zhang J-T, Narui T, Shibata S, Hirano E, Saito $\mathrm{H}$. Isolichenan, an $\alpha$-glucan isolated from the lichen Cetrariella islandica, repairs impaired learning behaviour and facilitates hippocampal synaptic plasticity. Proceedings Japan Academie 1999; 75, Ser. B: 219-23

${ }^{71}$ Smriga M, Saito H. Effect of selected thallophytic glucans on learning behaviour and short-term potentiation. Phytotherapy Research 2000; 14 (3): 153-5

${ }^{72}$ Nishikawa Y. et al. Studies on the water-soluble constituents of lichens. III. Changes in antitumor effect caused by modifications of pustulan- and lichenan-type glucans. Chemical \& Pharmaceutical Bulletin 1979; 27 (9): 2065-72

${ }^{73}$ Hirabayashi K, Iwata S, Ito M, Shigeta S, Narui T, Mori T, Shibata $S$. Inhibitory effect of a lichen polysaccharide sulfate, GE-3-S, on the replication of human immuno-deficiency virus (HIV) in vitro. Chemical \& Pharmaceutical Bulletin 1989; 37 (9): 2410-12

${ }^{74}$ Bohn JA, BeMiller JN. ( $1 \rightarrow 3$ )- $\beta$-D-Glucans as biological response modifiers. Carbohydrate Polymers 1995; $28: 3-14$

${ }^{75}$ Maeda YY, Chihara G. Lentinan and other antitumoural polysaccharides. In: Wagner $\mathrm{H}$, editor. Immunomodulatory Agents from Plants. Basel: Birkhauser Verlag, 1999: $203-23$

\section{Dr. E. S. Olafsdottir}

Faculty of Pharmacy University of Iceland

Hagi, Hofsvallagata 53

107 Reykjavik

Iceland

E-mail: elinsol@hi.is

Fax: +354 5254071 